\title{
THE IMPACT OF TOURISM ON RURAL DEVELOPMENT - EXAMPLE OF UNDEVELOPED
} VILLAGES IN REPUBLIC OF SERBIA

Drago Cvijanović* iD , Tamara Gajić**, Dušica Cvijanović***

DOI: $10.51558 / 2303-680 X .2021 .19 .1 .35$

\section{Abstract}

The aim of the research in this paper is to determine which factors the local population identifies as those that can, through the development of tourism, most influence or predict rural development or revitalization in the Republic of Serbia. In order to examine this, the survey was conducted during 2019, on a total sample of 680 respondents, in 45 rural municipalities in the country. The authors used a modified questionnaire, containing four groups of factors, with adequate 22 questions for research on a given issue. The SPSS AMOS software, version 26.00, was used for data analysis and processing. The authors checked the reliability of the questionnaire, whose value proved to be very good, and confirmed the grouping into exactly four groups of factors by Factor analysis. Descriptive statistical analysis yielded average scores for given items. The obtained suitability indices indicated the agreement of the Structural structural equation modeling (SEM) with the data, as well as the quality of the research and the confirmation of the hypotheses. The obtained results of the SEM analysis showed that there is no statistically significant difference in the impact of given factors in predicting rural development, and that the local population has a positive attitude about the impact of tourism on rural development.

Keywords: rural development, SEM, tourism, Republic of Serbia.

JEL: R20, L83, Z32

\section{Introduction}

Rural areas in the Republic of Serbia are rich in significant natural and cultural development resources, but despite that, villages lag far behind urban areas when it comes to development. There is also a high rate of rural-urban migration, which is usually one-way (Cvijanović \& Gajić,

2020). Rural tourism can really change the socioeconomic picture of a rural area, and the positive effects are multiple: agricultural development, new jobs, craft development, reduction of the negative trend of migration to cities, preservation of the natural environment (ecotourism), but also local culture, traditions and customs (ethnotourism), as well as greater chances for building better roads and improving infrastructure (Meng, 2014; Eslami et al., 2019; Bhat et al., 2020). According to the data of the Republic Bureau of Statistics, in the Republic of Serbia, rural tourism, as an activity, is recognized in 50 villages with about 3,000 beds. About $85 \%$ of the total territory of Serbia is occupied by rural areas where over $40 \%$ of the total population lives. There are 4,709 settlements in Serbia, i.e., villages (according to the Constitution, there is no category of villages), and 1,200 which have less than 50 inhabitants are in the phase of disappearance, (Gajić et al., 2020a; 2020b). The aim was to establish a model for predicting the strength of the impact of factors created by tourism on rural development, using the results of similar research.

\section{Literature review}

\subsection{Revitalization of villages in the Republic of} Serbia

The rural areas of the Republic of Serbia are generally in crisis. Villagers make up $45 \%$ of the total population, but still bear the brunt of poverty, malnutrition and poor quality of life. Statistics show that the rural poverty rate is $17 \%$ (compared to $8 \%$ in urban areas) (Cvijanović \& Gajić, 2020).

Many rural areas lack basic services such as education, health, roads, water and sanitation,

Faculty of Hotel Management and Tourism in Vrnjačka Banja, University of Kragujevac, Serbia, dvcmmv@gmail.com

** Geographical Institute "Jovan Cvijić", Serbian Academy of Sciences and Arts (SASA), Belgrade, Serbia; Institute of Sports, Tourism and Service, South Ural State University, Chelyabinsk, Russia, tamara.gajic.1977@gmail.com

*** Elementary school "Vožd Karađorđe" Jakovo, Serbia. dusicanikolic14@gmail.com 
and suffer from rising levels of pollution and declining natural resources (Li et al., 1987; Chen et al., 2020).

Some authors point out that it is time for a dramatic transformation across the system to make rural areas more productive, sustainable, climate-resilient, healthy and more attractive places to live and to develop tourism (Akis et al., 1996; Zhu et al., 2017). Revitalization of rural areas, through tourism, is essential for achieving this transformation and achieving specific goals in the long run. Although agricultural production is crucial for the rural economy of Serbia, it can still be said that the revitalization of the village through tourism can surpass agriculture, because it includes development of non-agricultural opportunities and makes the most modern technology and innovations a link to rural economic growth (Allen et al., 1988; Wang \& Pfister, 2008; Vuković et al., 2010; 2012; Garau, 2015; Alrwajfah et al., 2020). Revitalization of rural areas can also dramatically improve access to basic services for rural residents. For example, in Bangladesh, improved rural roads reduced extreme poverty by 3 to 6 percent, while increasing secondary school enrollment for both boys and girls (Ahmed, 2017). China chose the revitalization approach when in 2018 it announced a new strategy to close the growing income gap between villages and cities and improve the quality of life in rural areas (Tao et al., 2018; Zhou, 2020). One of the main drivers of rural revitalization is the principle of rurbanomics, an approach that emphasizes the links between the rural and urban economy. Growing urbanization in most countries increases the importance of rural areas (Asadzadeh et al., 2017). Demand for food, a varied diet and goods and services that the rural economy can meet is growing. Rurbanomia, therefore, sets rural and urban economies as equal partners (Shariff \& Abidin, 2013). In 2018, China announced a new strategy to close the growing income gap between villages and cities and improve the quality of life in rural areas. Zeng et al. (2019), emphasize the importance of reviewing the characteristics and activities of the rural area in order to make them attractive for tourism, and to link rural tourism with the social, cultural and economic elements of rural areas (Budenau, 2005). Tao et al. (2018), point out that tourism has become an important driving force for rural rejuvenation and spatial in the last 30 years (Sindair, 2017). They also point out that the socio-economic structure, have significantly influenced the revitalization of space, that the ecological burden on the environment has increased, and rural space has become increasingly sensitive (Moric, 2013; Wang, 2013).

\subsection{The impact of tourism on the revitalization of villages}

The development of rural tourism in the Republic of Serbia is a part of the project assisted by the Ministry of Agriculture, Forestry and Water Management, for the allocation of incentives for agricultural development. Households that have decided to make rural tourism a secondary activity, along with agriculture, earn a gross income of $€ 2,000$ to 10,000 a year, or an average of about $€ 5,000$ (Gajić et al., 2020a). The project was supported by the Ministries of Economy and Regional Development and the Diaspora. The partners are the Tourist Organization of Serbia and more than 40 tourist organizations of municipalities and cities and associations of entrepreneurs (Cvijanović \& Gajić, 2020). Rural tourism is a good example of diversification of the rural economy, because it promotes the multifunctionality of the rural economy, affects the financial position of farmers and the general development of the village, and brings employment to young people (Tosun, 2006; Bagri \& Kala, 2010). The average household income from rural tourism is now rising from $€ 200$ to $€ 440$ per month (Gajić et al., 2020b). Many of these households reduce their agricultural activities to a purely symbolic measure, because they no longer have time to engage in agriculture as they achieve a greater financial effect through tourism. Young people do not leave the village because they do not want to work 14 hours a day in the city for a miserable salary. They will stay at their hearths (where they earn much more), will welcome guests and will do work that makes them satisfied and happy (Clarke, 2005; Marin et al., 2009; Xu et al., 2010). Rural tourism contributes to the preservation of the rural environment and cultural heritage (Canoves et al., 2004). Rural development economically motivates the local population to stay there 
with a realistic prospect of a secure source of profit. These features of rural areas cannot be declared absolute, which implies the existence of a large number of varieties on the scale between predominantly rural and absolutely urban centers (Cui \& Ryan, 2011; Stylidis et al., 2014; Rasoolimanesh et al., 2017). Developing rural tourism have some primary activities: to communicate with the entire environment, to respect all types of restrictions in rural areas (spatial, cultural, etc.), as well as to involve of local people in tourism development (Choi \& Murray, 2010; Nunkoo \& Gursoy, 2012).

\subsection{Attitude of the local population on the development of rural areas through tourism}

Ertuna \& Kırbaş (2012) in their research in rural areas of Turkey, emphasize the conclusion that the involvement of the local community is crucial for the revitalization and development of rural households, but that this is difficult to achieve in some parts of Turkey. Chang et al. (2018), indicate which factors negatively influence and which positively influence the decision of the local population to support tourism development.

Zeng et al. (2019) point out that the consciousness of tourists is changing more and more, from urban to rural, peaceful vacation in the countryside. For that reason, it is necessary to direct all measures towards the revitalization of rural areas, through the development of tourist and catering activities. Chun Liu (2005), in his research into rural tourism development in south Taiwan points to the importance of rural tourism development and the influence of the local population. He investigated the impact of factors through tourism, on the development and revitalization of rural areas, and the attitude of the local population, during 2001, on a total valid sample of 150 respondents. He points out that the positive attitude of the local population towards the development of rural tourism is essential. His research was conducted during the summer of 2001 at two locations, Tainan County in Baihe Chen and Danei Shung, both located in south Taiwan, Tainan County. Muresan et al. (2016), also investigated the impact of the local population on rural development, as well as the impact of economic, social, environmental and physical components on the sustainability of development. The aim of their research was to identify the support of the local community towards sustainable development of tourism in the Nord West region of Romania. This research, has focus both on negative and positive impacts of tourism on local communities, on a total sample of 433 respondents. They came to the conclusion that the largest percentage of the respondents was for further development of tourism, and the environmental component has the strongest influence as a predictor of future sustainable development. Marzuki (2011, p. 25), in his research on a total sample of 392 respondents, presented the attitude of the respondents. An exploratory factor analysis (EFA) using principal component analysis was carried out to identify the respondents 'perception of the impacts from tourism development. The findings from data analysis identified three factors representing $55.63 \%$ of the explained variance extracted from 21 variables, namely: costs from tourism development, benefits from tourism development, and socio-economic effects from tourism development. Finally, the findings from data analysis suggested that tourism development in Langkawi has provided more benefits that costs to the residents. Mbaiwa (2005), highlights some of the positive socio-cultural impacts of tourism development in the Okavango Delta, Botswana, which include income generation and employment opportunities both from community tourism projects, as well as from safari companies, infrastructure development such as airports and airfields, blackened roads, hotels, lodgings and camps, and improvement of social services such as banking, health, telecommunications and access to electricity.

\section{Methodology}

The reserach was tested on a sample of 680 randomly selected respondents from the local population, out of a total of 800 distributed questionnaires during 2019. The research was conducted in 45 rural municipalities in the Republic of Serbia where accommodation and food services are provided. The highest percentage of questionnaires is from Central Serbia (250), followed by Eastern Serbia (112), Western Serbia (180), and Vojvodina (138). There are a total of 4,243 settlements in Central 
Serbia, of which 3,300 are rural (78.5\%). A structured questionnaire was taken from the research by Chun Liu (2005), as well as Muresan et al. (2016). The questionnaire contains four categories of factors: environmental, economic, sociocultural and physical and a total of 22 questions. The aim was to determine which of the factors can play the role of a strong predictor in the future development and business of rural tourist households. The aim was to determine which of the factors may play the role of a strong predictor in the future development and business of rural tourist households. Also, the goal was to assess the local population on the impact of factors on the development of rural areas with the help of tourism. The SPSS AMOS software, version 26.00, was used for data analysis and processing. We first checked the reliability of the questionnaire, which proved to be very good because the value of Cronbach's Alpha was $\alpha=0.870$. Then, factor analysis confirmed the extractions and the existence of four groups of factors, and the authors proceeded to further data processing. Descriptive statistical analysis gave good estimates for almost all factors influencing the development or revitalization of the village. Data from different model agreement indices and research data were taken, more precisely agreement indices that do not have the same logic and converge with each other, so we could draw conclusions with certainty about the quality of the model and the confirmation of the hypothesis. Tabular representations are given, as well as a path diagram of the structural model. We also confirmed reliability, through the Kaiser-Meyer-Olkin Measure of Sampling Adequacy, which value has to be greater than 0.6 , in order for each item to gain in reliability. The obtained results of the SEM analysis indicate that the factors had an almost equal influence in predicting future rural development through tourism and that the local population expressed a positive opinion on the impact of tourism on rural development. The obtained data and the overall research have a wide social, scientific and economic significance for the current and future business of rural households, both in the Republic of Serbia and in the region.

The following multiple indicators were selected to gain insight into the quality of the model: GFI (a measure of the relative magnitude of variance and covariance jointly explained by the model or a comparative agreement index); NFI (standardized agreement index; represents the proportion of total disagreement that is reduced using the proposed model); RNFI (relative standardized matching index; estimates the extent to which the causal model approximates the data, taking into account only the relationships between the latent variables of the structural equation); TL (Tucker Lewis match index; shows how much better the proposed model describes the data compared to the null model, taking into account the degrees of freedom); CFI (Comparative Fit Index); and RMSEA (square root of the average squared error approximation which should be less than 0.8 ). The stated agreement indices must be greater than 0.900 to be considered indicators of good agreement (except for the REMSEA indicator) (Bentler and Bonett, 1980).

Table 1. Factors influencing tourism on revitalization or rural development

Damage natural environment and landscape

Tourism causes overcrowding problems for residents

Tourism increases the air pollution

Tourists use too much water

Environment Tourism results in more litter in an area

Tourism development negatively affects recreational facilities and entertainment

Construction of tourist facilities destroys the environment Tourism increases traffic problems

Tourism plays an important role in the economic development of the area Tourism improves locals'standard of living Tourism increases a community's

Economic tax revenue Tourism creates new jobs for locals' Tourism results in an increase in the cost of living Tourism diversifies the rural economy Revenue from tourism

Social and Tourism provides incentives for Cultural restoration of traditional houses 


\begin{tabular}{l|l} 
& $\begin{array}{l}\text { Interaction with tourists is a } \\
\text { positive experience } \\
\text { Shopping and restaurants are } \\
\text { better as a result of tourism } \\
\text { Tourism development enhances } \\
\text { more recreational opportunities } \\
\text { for locals' } \\
\text { Tourism improves traffic } \\
\text { network } \\
\text { Tourism improves living utilities } \\
\text { infrastructure (supply of water, } \\
\text { sewage, electricity, etc.) } \\
\text { Quality of public services is } \\
\text { better }\end{array}$
\end{tabular}

Source: Authors downloaded and modified questionnaire Chun-Chu \& Liu (2005); Muresan et al. (2016)).

The authors set the following research hypotheses:

H1: The local population has a positive assessment of the impact of tourism on development of rural areas

H2: There is statistical significance in the predictor power offactors to predict future rural development

H2a: There is no statistical significance in the predictor power of factors to predict future rural development

\section{Results and discussion}

The research was conducted on a total sample of 800 respondents, but 680 survey questionnaires were taken for processing due to the validity of the given answers. Of the total number of the valid study participants, $64.8 \%$ were men, while $35.2 \%$ were women. In the rural municipalities covered by the survey, $42.5 \%$ of the respondents were between the ages of 51 and 70 , followed by $33.9 \%$ between the ages of 31 and 50 , and $23.6 \%$ of the respondents aged18 to 30 .

The largest percentage of the respondents completed secondary school (39.8\%), followed by university-educated (34.7\%), and those who completed primary school $(25.5 \%)$. Of the total number of the survey participants, $53.7 \%$ had a monthly income of $€ 300$ to $€ 400$, followed by $26.2 \%$ with less than $€ 300$, and $20.1 \%$ with more than €400.

Reliability statistics is most often used with multiple Likert questions in a survey/questionnaire that make up the scale and we wanted to determine if the scale is reliable. Cronbach's Alpha must be greater than 0.07 . In this case, the value was 0.870 , which indicated a high reliability of the questionnaire.

Table 2. Reliability Statistics

\begin{tabular}{|r|r|}
\hline Cronbach's Alpha & N of Items \\
\hline .870 & 22 \\
\hline
\end{tabular}

Source: Authors' research

Since factor analysis uses correlations between variables, before starting the procedure it should be checked whether the variables are correlated.

For this purpose, Bartlett's sphericity test was used. It tests the null hypothesis that the matrix is intercorrelation of variables inserted into identity matrix procedures, i.e., that all correlations between variables are equal zeros.

Table 3. KMO and Bartlett's Test

\begin{tabular}{|c|c|r|}
\hline \multicolumn{2}{|c|}{$\begin{array}{c}\text { Kaiser-Meyer-Olkin Measure of } \\
\text { Sampling Adequacy. }\end{array}$} & .889 \\
\hline \multirow{3}{*}{$\begin{array}{c}\text { Bartlett's Test of } \\
\text { Sphericity }\end{array}$} & $\begin{array}{c}\text { Approx. Chi- } \\
\text { Square }\end{array}$ & 15655.566 \\
\cline { 2 - 3 } & df & 231 \\
\cline { 2 - 3 } & Sig. & .000 \\
\hline
\end{tabular}

Source: Authors' research

The Kaiser-Meyer-Olkin Measure of Sampling Adequacy value is required to be equal to or greater than 0.6 , in our example it was 0.889 . The results of the Bartlett's test $p<0.001$ had statistical significance, which meant we could proceed with the factor analysis method (here we chose the Principal Components method).

We also got the Community Matrix in which the data on the proportion of variance of each variable were explained by extracted factors, i.e., which is its communality (column Extraction).

The value of the Bartlett's test for the statistical significance of the correlation matrix $\chi^{2}=$ 15655.566, with 231 degrees of freedom and a statistical significance $\mathrm{p}=0.000$, also confirmed the suitability of statistical processing of the collected data by factor analysis. 
Table 4. Extraction Method: Principal Component Analysis - Community Matrix

\begin{tabular}{|l|r|r|} 
& Initial & Extraction \\
\hline Damage natural environment and landscape & 1.000 & .576 \\
\hline Tourism cause overcrowding problems for residents & 1.000 & .714 \\
\hline Tourism increase the air pollution & 1.000 & .648 \\
\hline Tourists use too much water & 1.000 & .591 \\
\hline Tourism results in more litter in an area & 1.000 & .795 \\
\hline Tourism development negatively affects the recreational facilities and entertainment & 1.000 & .765 \\
\hline The construction of tourist facilities destroy the environment & 1.000 & .876 \\
\hline Increase traffic problems & 1.000 & .868 \\
\hline Tourism plays an important role in the economic development of the area & 1.000 & .840 \\
\hline Tourism improves locals'standard of living & 1.000 & .824 \\
\hline Tourism increases a community's tax revenue & 1.000 & .879 \\
\hline Tourism create new jobs for locals' & 1.000 & .840 \\
\hline Tourism results in an increase in the cost of living & 1.000 & .636 \\
\hline Tourism diversifies the rural economy & 1.000 & .638 \\
\hline Revenue from tourism & 1.000 & .736 \\
\hline Tourism provide incentives for restoration of traditional houses & 1.000 & .779 \\
\hline Interaction with tourists is a positive experience & 1.000 & .853 \\
\hline Shopping and restaurants option is better as a result of tourism & 1.000 & .899 \\
\hline Tourism development enhance more recreational opportunities for locals' & 1.000 & .910 \\
\hline Improves traffic network & 1.000 & .890 \\
\hline Improves living utilities infrastructure (supply of water, sewage, electric etc.) & 1.000 & .879 \\
\hline Quality of public services in better & 1.000 & .767 \\
\hline
\end{tabular}

\section{Table 5. Descriptive Statistics of items and factors}

\begin{tabular}{|c|c|c|}
\hline & Mean & Sd \\
\hline Damage natural environment and landscape & 2.79 & 1.224 \\
\hline Tourism cause overcrowding problems for residents & 2.93 & 1.091 \\
\hline Tourism increase the air pollution & 3.05 & 1.314 \\
\hline Tourists use too much water & 3.08 & 1.245 \\
\hline Tourism results in more litter in an area & 2.93 & 1.165 \\
\hline Tourism development negatively affects the recreational facilities and entertainment & 2.92 & 1.280 \\
\hline The construction of tourist facilities destroy the environment & 2.95 & 1.235 \\
\hline Increase traffic problems & 2.95 & 1.232 \\
\hline Tourism plays an important role in the economic development of the area & 3.80 & 1.316 \\
\hline Tourism improves locals' standard of living & 3.79 & 1.326 \\
\hline Tourism increases a community's tax revenue & 3.85 & 1.312 \\
\hline Tourism create new jobs for locals' & 3.85 & 1.315 \\
\hline Tourism results in an increase in the cost of living & 3.50 & 1.417 \\
\hline Tourism diversifies the rural economy & 3.46 & 1.411 \\
\hline Revenue from tourism & 3.64 & 1.319 \\
\hline Tourism provide incentives for restoration of traditional houses & 3.38 & 1.376 \\
\hline Interaction with tourists is a positive experience & 3.22 & 1.348 \\
\hline Shopping and restaurants option is better as a result of tourism & 3.19 & 1.328 \\
\hline Tourism development enhance more recreational opportunities for locals' & 3.22 & 1.342 \\
\hline Improves traffic network & 3.21 & 1.338 \\
\hline Improves living utilities infrastructure (supply of water, sewage, electric etc.) & 3.19 & 1.323 \\
\hline Quality of public services in better & 3.31 & 1.358 \\
\hline ENVIRONMENTAL & 2.95 & 0.850 \\
\hline ECONOMIC & 3.69 & 1.147 \\
\hline SOCIAL AND CULTURAL & 3.25 & 1.262 \\
\hline PHYSICAL & 3.23 & 1.256 \\
\hline
\end{tabular}

Source: Authors' research 


\section{Environment Factors}

Table 5 shows descriptive values for all groups and a total of 22 research variables. It is noticed that in the group Environment, the highest average grade was given to the item Tourists use too much water $\mathrm{m}=3.08(\mathrm{sd}=1.245)$. The locals believe that tourists use too much fresh water. Then, a high value of the arithmetic mean was obtained by the item Tourism increases the air pollution $\mathrm{m}=3.05(\mathrm{sd}=1.314)$. Compared to other environmental problems, such as water and soil pollution, the air pollution is much more visible and can be more easily noticed by the public, which justifies the high impact it can have on tourism in a given destination (Lee, 2012; Naidoo \& Sharpley, 2015). In the research, by Asadzadeh and Mousavi (2017), the relationship between tourism and the environment is seen as complex, but with many activities that can have negative effects on the environment. They place special emphasis on air pollution through the development of tourism. The item Tourism Damages natural environment and landscape, carried an average score of $\mathrm{m}=2.79$, while the item Tourism causes overcrowding problems for residents had a rating of $2.93(\mathrm{sd}=1.091)$. The local population saw a great danger from mass development of tourism in the increasedamount of garbage. The respondents rated the item Tourism results in more litter in an area with the following value $\mathrm{m}=2.93$ ( $\mathrm{sd}=$ 1.165). Similar values were given to the items related to the development of tourism having a negative impact on the development of tourist infrastructure in rural areas. The average score for Environmental factors was 2.95 (sd = 0.850 ).

\section{Economic factors}

Observing the group of economic factors, it was noticed that, the items Tourism increases a community's tax revenue and Tourism creates new jobs for locals had the highest average grade $(\mathrm{m}=3.85)$. There is plenty of research on tourism and economic development, with a critical attitude towards the long-term implications of tourism, especially in developing countries (Negrusa et al., 2007; Lepp, 2007). At the same time, governments around the world, and, to a lesser extent, international aid organizations, have showed a broad interest in tourism and have allocated significant amounts of public funds to national and regional tourism promotion. Tourism in general has become one of the main cultural and economic powers in the world today and is considered an important tool for the benefit of local communities (Li, 2002; Gursoy et al., 2018). The fact is confirmed by the evaluation in the research, where the impact of tourism on the economic development of rural areas was estimated at $3.80(\mathrm{sd}=1.316)$. The high average grade was given to the item Tourism improves locals' standard of living $\mathrm{m}=3.79$, and Revenue from tourism taxes activity should be invested in future development of tourism ( $\mathrm{m}=$ 3.64). The local population believes that tourism will increase the cost of living and bring about the diversification of the rural economy. Economic factors with a total of seven items carried the value of the average score $m$ $=3.69(\mathrm{sd}=1.147)$.

\section{Social and cultural factors}

Four items of the research belonged to social factors. The average rate for social factors was $\mathrm{m}=3.25$. The item Tourism provides incentives for restoration of traditional houses was rated with an average score of 3.38, while the item Interaction with tourists was rated slightly lower with an average score of $\mathrm{m}=3.22$. However, in contrast to the above-mentioned similar research, no conflicts between the local population and tourists were observed in this area. In general, these are high scores of items of the social factor. The lowest rated item was Shopping and restaurants are better as a result of tourism, with $m=3.19$, because the offer was weaker. Often the community will accept tourism, not realizing the impact it can have on the culture and society of the community (Ling \& Hui, 2016). The social and cultural impacts of tourism can result in changes in the patterns of behavior, lifestyle, and quality of life of residents or locals. Tourism, like all business ventures, can have an impact on communities and can be positive or negative, and sometimes both.

\section{Physical factors}

The group of Physical Factors had an average grade of 3.23 ( $\mathrm{sd}=1.256$ ), where the highest grade was given to the item Quality of public 
services is better $\mathrm{m}=3.31(\mathrm{sd}=1.358)$, followed by Tourism improves traffic network $\mathrm{m}=3.21$ ( $\mathrm{sd}=1.338$ ). The item Tourism improves living utilities infrastructure (supply of water, sewage, electricity, etc.) was rated by the local population with an average score of $\mathrm{m}=3.19$ (sd = 1.323).

The local population was of the opinion that tourism will improve the infrastructure, in terms of public service, traffic, and communal infrastructure. The current situation is not commendable, because rural households that provide accommodation and food services very often have poor transport connections, their communal infrastructure is at a low level, and the entire public sector needs to be improved.

Asadzadeh and Mousavi (2017), in their research came to similar assessments: the first factor of costs of tourism development suggested that tourism resulted in an increase in social problems (mean $=3.55$ ), tourism caused traffic congestion, noise and pollution in the islands (mean = 3.57), tourism infrastructure development destroyed the natural environment in the islands (mean = 3.55), tourism development resulted in increased environmental protection (mean $=$ 3.89), tourism improved the quality of life of local residents (mean $=4.27$ ), and interaction with foreign tourists had a positive experience for local residents $($ mean $=4.13)$.

The indices are given in Table 6, which indicates an acceptable match of the model with the data. The values of NFI, RNFI, TL and CFI exceeded 0.900, which means that the proposed model reduced the total discrepancy between the model and the data by more than $90 \%$. The value of RMSEA was equal to 0.05 , which is less than the limit value of 0.08 .

The $\chi^{2}$ test yielded a value of 15655.566 which, evaluated with 231 degrees of freedom, had a corresponding p-value of 0.00 .

This p-value was too high to reject the null of a good fit. Chi - square was an observation of a random variable that has an approximate chi distribution with 231 degrees of freedom.
Table 6. Indicators of agreement of the structural model with the data

\begin{tabular}{|c|c|c|}
\hline Fit statistic & Recommended & Obtained \\
\hline CFI & $>0,90$ & 0.99 \\
\hline RMSEA & $<0,05$ & 0.04 \\
\hline GFI & $>0,90$ & 0.99 \\
\hline NFI & $>0,90$ & 0.98 \\
\hline TL & $>0,90$ & 0.98 \\
\hline RNFI & $>0,90$ & 0.97 \\
\hline
\end{tabular}

Source: Authors' research

The standardized regression weights can be interpreted as the correlation between the observed variable and the corresponding common factor. All six variables had moderate to strong standardized loadings on factor (1.000).

Table 7. Standardized Regression Weights

(loadings on Factor Rural development)

\begin{tabular}{|r|c|c|c|c|}
\hline & Estimate & S.E. & C.R. & $\mathrm{P}$ \\
\hline Environment & 1.340 & .083 & 16.159 & $* * *$ \\
\hline Economic & 1.144 & .090 & 12.769 & $* * *$ \\
\hline $\begin{array}{r}\text { Social and } \\
\text { Cultural }\end{array}$ & 1.724 & .098 & 17.573 & $* * *$ \\
\hline Physical & 1.265 & .096 & 13.129 & $* * *$ \\
\hline
\end{tabular}

Source: Authors' research

A total of first eight items belonged to environmental factor. It was observed that there was statistical significance in the influence of Environmental factors on rural development. The first covariance was estimated to be 1.340 , with an estimate of the standard covariance error S.E $=0.083$. The estimate 1.340 was an observation of an approximately normally distributed random variable centered around the covariance of a population with a standard deviation of 0.083 . These figures served to construct a 95\% confidence interval on the covariance population by calculating Estimate and S.E. The Critical Ratio (CR) was obtained by dividing the covariance estimate by its standard error. At a statistical significance of $\mathrm{p}<0.05$, any CR exceeding 1.96 is considered significant. If this value is achieved, it is considered that the covariance between the variables differs significantly from 0 , at the level of significance $\mathrm{p}<0.05$. It was noticed that this value was above than 1.96, therefore it can be concluded that the relaxation significantly affected the variable. A large $P$ in addition to $C R$ gave about two tailed $\mathrm{p}$ values to test the hypothesis. In this case, the covariance between the variables 
differed from 0 , with $\mathrm{p}=0.0$. Calculation $\mathrm{P}$ implies that parameter estimates were normally distributed, and were accurate only in large samples. Economic factors had a total of seven research items, and it is noticed that the factor was estimated to be 1.144 , slightly less than environmental factors ( $\mathrm{S} . \mathrm{E}=0.090, \mathrm{CR}=$ $12.7, \mathrm{P}=0.00$ ). Socio cultural factor had the strongest standardized loadings, and the estimate was 1.724 (S.E = 0.098, C.E = 17.57). Then came Physical factors with estimate 1.265. They were all reliable indicators for rural revitalization.

Table 8. Standardized Regression Weights for all items

\begin{tabular}{|c|c|c|c|c|}
\hline & Estimate & S.E. & C.R. & $\mathrm{P}$ \\
\hline $\begin{array}{l}\text { Increase traffic } \\
\text { problems }\end{array}$ & 2.946 & .047 & 62.338 & $* * *$ \\
\hline $\begin{array}{c}\text { The construction } \\
\text { of tourist facilities } \\
\text { destroy the } \\
\text { environment }\end{array}$ & 2.954 & .047 & 62.385 & $* * *$ \\
\hline $\begin{array}{c}\text { Tourism } \\
\text { development } \\
\text { negatively affects } \\
\text { the recreational } \\
\text { facilities and } \\
\text { entertainment }\end{array}$ & 2.922 & .049 & 59.521 & $* * *$ \\
\hline $\begin{array}{c}\text { Tourism results in } \\
\text { more litter in an } \\
\text { area }\end{array}$ & 2.934 & .045 & 65.655 & $* * *$ \\
\hline $\begin{array}{l}\text { Tourists use too } \\
\text { much water }\end{array}$ & 3.081 & .048 & 64.530 & $* * *$ \\
\hline $\begin{array}{l}\text { Tourism increase } \\
\text { the air pollution }\end{array}$ & 3.046 & .050 & 60.463 & $* * *$ \\
\hline $\begin{array}{l}\text { Tourism cause } \\
\text { overcrowding } \\
\text { problems for } \\
\text { residents }\end{array}$ & 2.934 & .042 & 70.134 & $* * *$ \\
\hline $\begin{array}{c}\text { Damage natural } \\
\text { environment and } \\
\text { landscape }\end{array}$ & 2.794 & .047 & 59.532 & $* * *$ \\
\hline $\begin{array}{c}\text { Revenue from } \\
\text { tourism }\end{array}$ & 3.641 & .051 & 72.015 & $* * *$ \\
\hline $\begin{array}{c}\text { Tourism } \\
\text { diversifies the } \\
\text { rural economy }\end{array}$ & 3.463 & .054 & 64.025 & $* * *$ \\
\hline $\begin{array}{l}\text { Tourism results in } \\
\text { an increase in the } \\
\text { cost of living }\end{array}$ & 3.496 & 054 & 64.316 & *** \\
\hline $\begin{array}{c}\text { Tourism create } \\
\text { new jobs for locals' }\end{array}$ & 3.846 & .050 & 76.241 & $* * *$ \\
\hline $\begin{array}{c}\text { Tourism increases } \\
\text { a community's tax } \\
\text { revenue }\end{array}$ & 3.847 & .050 & 76.488 & $* * *$ \\
\hline $\begin{array}{l}\text { Tourism improves } \\
\text { locals standard of } \\
\text { living }\end{array}$ & 3.793 & .051 & 74.591 & $* * *$ \\
\hline $\begin{array}{l}\text { Tourism plays an } \\
\text { important role in }\end{array}$ & 3.803 & .050 & 75.370 & $* * *$ \\
\hline
\end{tabular}

\begin{tabular}{|c|c|c|c|c|}
\hline $\begin{array}{l}\text { the economic } \\
\text { development of } \\
\text { the area }\end{array}$ & & & & \\
\hline $\begin{array}{c}\text { Tourism } \\
\text { development } \\
\text { enhance more } \\
\text { recreational } \\
\text { opportunities for } \\
\text { locals }\end{array}$ & 3.216 & .051 & 62.487 & $* * *$ \\
\hline $\begin{array}{c}\text { Shopping and } \\
\text { restaurants option } \\
\text { is better as a result } \\
\text { of tourism }\end{array}$ & 3.193 & .051 & 62.686 & $* * *$ \\
\hline $\begin{array}{l}\text { Interaction with } \\
\text { tourists is a } \\
\text { positive } \\
\text { experience } \\
\end{array}$ & 3.216 & .052 & 62.234 & $* * *$ \\
\hline $\begin{array}{l}\text { Tourism provide } \\
\text { incentives for } \\
\text { restoration of } \\
\text { traditional houses }\end{array}$ & 3.381 & .053 & 64.055 & $* * *$ \\
\hline $\begin{array}{l}\text { Quality of public } \\
\text { services in better }\end{array}$ & 3.312 & .052 & 63.603 & $* * *$ \\
\hline $\begin{array}{c}\text { Improves living } \\
\text { utilities } \\
\text { infrastructure } \\
\text { (supply of water, } \\
\text { sewage, electric } \\
\text { etc.) } \\
\end{array}$ & 3.193 & .051 & 62.949 & $* * *$ \\
\hline $\begin{array}{c}\text { Improves traffic } \\
\text { network }\end{array}$ & 3.209 & .051 & 62.521 & $* * *$ \\
\hline
\end{tabular}

Source: Author`s research, ${ }^{* * *} \mathrm{p}=0.00$, statistical significance (P).

The estimate of Socio-cultural covariance was the largest as seen from all items belonging to this factor, whose estimate exceeded the value 3. Significance in all items and their factor loadings were observed, the value was in all $p$ $=0.000$. To a lesser extent, environmental factors were estimated and their value was estimated somewhere below the average value of 3: Tourism increases traffic problems (estimate 2.96), The construction of tourist facilities destroys the environment (with an estimate of 2.95); Tourism development negatively affects the recreational facilities and entertainment $(E=2.92)$, Tourism results in more litter in an area $(\mathrm{E}=2.93)$, Tourism causes overcrowding problems for residents ( $\mathrm{E}$ $=2.93$ ), Tourism damages natural environment and landscape $(\mathrm{E}=2.79)$.

Diagram 1 gives an insight into the SEM model. 


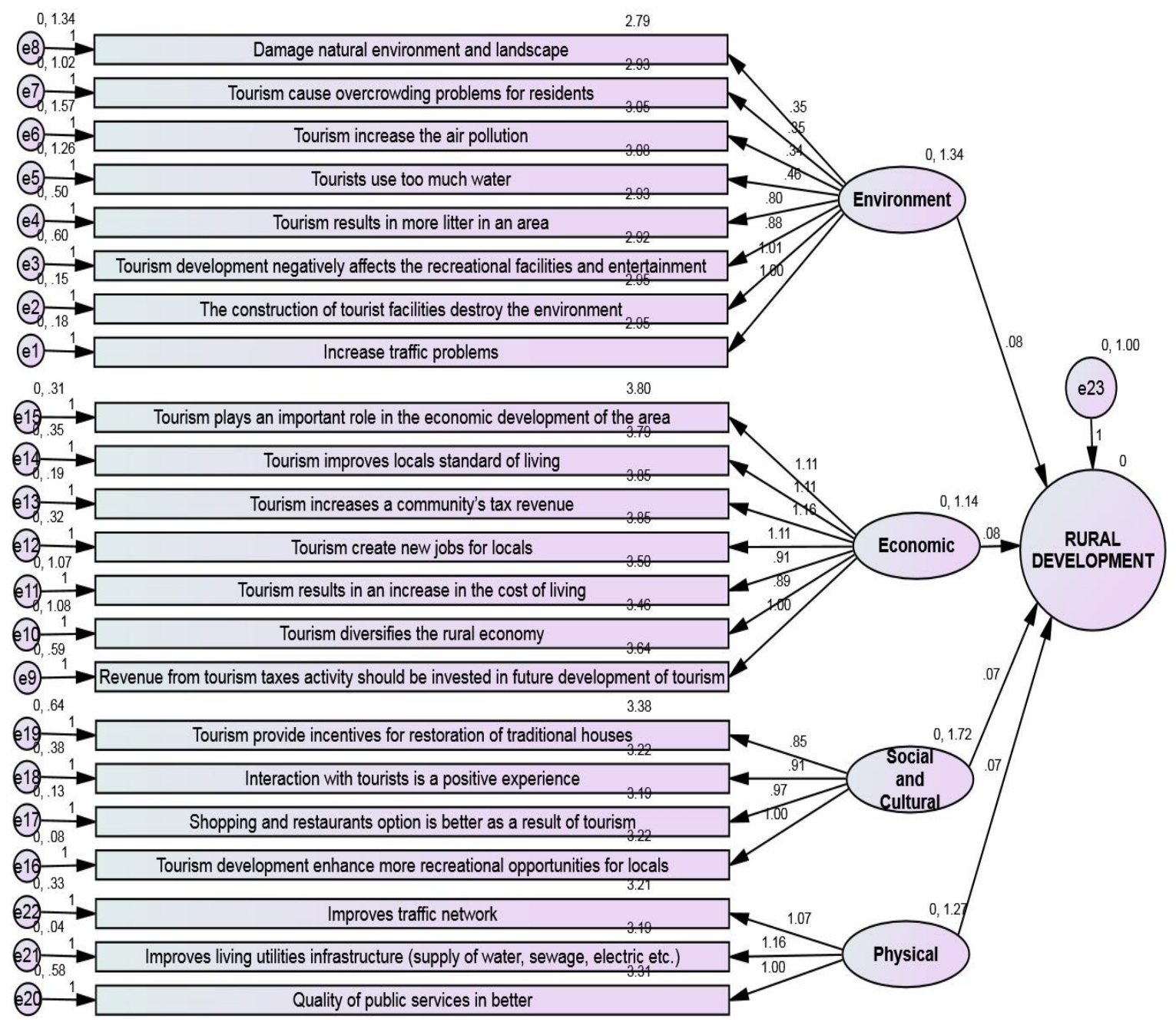

Diagram 1. Structural modeling (SEM)

Source: Author`s research

The arrows directed from independent latent variables to a dependent latent variable represent regression coefficients that indicate the influence, i.e., the relative contribution of one latent variable in the forecast of another latent variable. In the given diagram, it can be noticed that all the factors have an approximate impact on the development of rural areas. The local population generally has a positive attitude about the impact of tourism on rural development, but the factors do not have a pronounced statistical significance in predicting future development. More precisely, in approximate strength, all the factors can be predictors of rural development. Impact strength values are above 0.7 for Socio-cultural and Physical factors, while for Environmental and Economic factors they contribute to the prediction of rural development in the amount of 0.8 .

\section{Conclusion}

Serbia has exceptional potentials and natural resources for the development of various forms of rural tourism, and some of them are: ecotourism, spa, recreational, hunting and fishing tourism, religious, and agro-tourism. Rural tourism should contribute to the preservation of cultural heritage and the rural environment, but also motivate the local population to stay in the countryside (Fachrudin \& Lubis, 2016).

Tourism must have the basic function, which is to develop or revitalize rural areas in the Republic of Serbia. The main goal of rural tourism is, on the basis of tourist demand, to provide the rural population with additional income and thus improve their standard of living and reduce the number of departures, primarily of young people, from rural areas (Hai \& Alamgir, 2017). 
One of the most important segments within the rural tourism, especially in economically underdeveloped areas, is dealing with tourism within agricultural households.

As part of the overall rural tourism, this form can be realized through the providing accommodation (ranging from small-scale business, renting vacant rooms in the host's house, to more extensive investment in renovation and modernization of special facilities), equipping camping grounds, opening restaurants, and selling agricultural product.

The authors of the paper conducted a survey in 45 rural municipalities in the Republic of Serbia, in order to determine which of the factors most influence the future development of the village, through the tourism sector.

The survey was conducted on a total sample of 680 respondents from the local population. A modified questionnaire created by the authors who dealt with similar issues was used. The factors were divided into four groups, with a total of 22 elements or research questions. The respondents evaluated the given items, more precisely gave their position on how tourism through various factors can affect the rural development of the given rural municipalities. Relying on similar research and available literature, the authors approached data processing and the result analysis, through the SPSS AMOS 26.00 software.

Descriptive statistical analysis provides average and standard estimates for all factors and their items, as well as a description of the research participants. The reliability of the questionnaire was checked $(\alpha=0.870)$, and the grouping of items into four factors was confirmed with the help of factor analysis. It turned out that different indices of agreement of the structural model and data converge with each other, based on which the authors were able to draw conclusions and confirm the hypothesis with certainty. A diagram of a structural (SEM) model is given, with the path coefficients obtained by structural modeling.

Based on the presented research and various statistical analyzes, we came to the following conclusions:
- The local population generally has a positive attitude about the impact of tourism on rural development (initial hypothesis confirmed $\mathrm{H} 1$ )

- There is no statistically significant difference in the predictive power of the given factors, when it comes to predicting the future development of rural areas (hypothesis H2 denied, alternative $\mathrm{H} 2 \mathrm{a}$ confirmed).

Revitalization of villages in Serbia will not be a necessity, especially considering the state of the economy and long-term disproportions in spatial development in which the number and area of deserted villages and abandoned territories is increasing. Thus, the huge production potential of agricultural farms is excluded from production and left to degradation. With the shutdown of industry, cities are not able to absorb the influx of population, so the revival of villages is directly related to the rehumanization of life in cities (Lee, 2013). The development of tourism in the countryside, in an unpolluted natural environment, with a pronounced individualization of tourist demand and its more significant focus on non-standard tourist products is one of the bases of application (Ling \& Hui, 2016).

The results and conclusions of this study can contribute to the management of rural tourism development, both in the country and in similar destinations around the world. More attention needs to be paid to examining the impact of all factors and changes, thus creating an opportunity to develop future studies, helping to understand whether the findings obtained in our country are consistent and coherent with other regions, namely in the context where awareness of the importance of impact of local people and tourism on rural development is a growing phenomenon. The significance of this paper is reflected in the contribution of results from Serbia, because there is no similar research on a given topic from this area. The paper focuses on the analysis of basic factors or predictors of importance for defining the impact of tourism on rural areas, as well as for understanding the context, approach and concept of rural tourism. Emphasis is placed on factors and their strength of impact on household operations, and in what way and to 
what extent they predict future development. Changes within tourism result primarily from changes in structural elements, i.e., the structural transformation of tourism as a whole. The basic changes, which make tourism extremely turbulent, concern the significant action of factors from the environment, connected with the growing awareness of the need to preserve the basis of its development space, i.e., the natural environment. These changes have created the need for new considerations regarding the development of tourism, which are based on two basic postulates - protection and preservation of natural and cultural resources, on which the development of tourism is based, and highlighting the problem of social costs of tourism development. Revitalization of rural areas through tourism development strengthens the rural economy not only as drivers of food security, but also as springboards for national, regional and global value chains and as providers of quality environmental services. Revitalization of rural areas can also improve rural governance, ensuring that local people are held accountable in providing high quality services.

\section{References}

1. Ahmed, S. (2017). Developmental crises impacting United Nations Millennium Development Goals achievement in Bangladesh: A critical review. In Besada, $\mathrm{H}$., Agarwal, M., Polonenko, L. (Eds.), The global 2015 development agenda: Challenges and prospects. pp. 289-308.

2. Allen, L. R., Long, P.R., Perdue, R. R., \& Kieselbach, S. (1988). The impacts of tourism development in residents' perceptions of community life. Journal of Travel Research. 26, 16-21.

3. Alrwajfah, M. M., Almeida-García, F., \& Cortés-Macías, R. (2020). Females' perspectives on tourism's impact and their employment in the sector: The case of Petra, Jordan. Tourism Management. 78. doi.org/10.1016/j.tourman.2019.104069

4. Akis, S., Peristianis, N., \& Warner., J. (1996). Residents attitudes to tourism development: The case of Cyprus. Tourism Management. 17, pp. 481-494.

5. Asadzadeh, A., \& Mousavi, M. S. S (2017). The Role of Tourism on the Environment and Its Governing Law. Electronic Journal of Biology. 13(2), pp. 152-158.

6. Bagri, S. C., \& Kala, D. (2016). Residents' attitudes toward tourism development and impacts in KotiKanasar, Indroli, Pattyur tourism circuit of Uttarakhand state, India. PASOS Revista de Turismo y Partrimonia Cultural. 14(1), 23-39.

7. Bhat, A. A., \& Mishra, R. K. (2020). Demographic characteristics and residents' attitude towards tourism development: A case of Kashmir region. Journal of Public Affairs. 21-79.

8. Bentler, P. M., \& Bonett, D. G. (1980). Significance tests and goodness of fit in the analysis of covariance structures. Psychological Bulletin .88(3), pp.588-606.

9. Budeanu, A. (2005). Impacts and responsibilities for sustainable tourism: A tour operator's perspective. J. Clean. Product. 13, pp. 89-9

10. Cánoves, G., Villarino, M., Priestley, G. . \& Blanco, A. (2004). Rural Tourism in Spain: An Analysis of Recent Evolution. Geoforum. 35, pp.755-769.

11. Tosun, C. (2006). Expected nature of community participation in tourism development. Tourism Management. 27, 3, pp. 493-504.

12. Chang I., K. G., Chien, H., C., \& Hen, H. (2018). The Impacts of Tourism Development in Rural Indigenous Destinations: An Investigation of the Local Residents' Perception Using Choice Modeling. Sustainability. 10, pp. 2-15.

13. Clarke, J. (2005). Effective Marketing for Rural Tourism, Rural Tourism and Sustainable Business, Clevedon. Channel View Publications. pp. 87-102.

14. Chen J., Yang X., Wen X., \& Deng M. (2020). Theoretical framework and empirical evidence of rural adaptive evolution in the context of Tourism Development. Journal of Natural Resources. pp. 16.

15. Choi, H. C., \& Murray, I. (2010). Resident attitudes toward sustainable community tourism. Journal of Sustainable Tourism. 18(5), pp. 75-94.

16. Chun, L. (2005). Residents Attitudes to Rural Tourism Development in South Taiwan. Journal of Applied Sciences. 5, pp. 1363-1368.

17. Cui, X., \& Ryan, C. (2011). Perceptions of place, modernity and the impacts of 
tourism - differences among rural and urban residents of Ankang, China: a likelihood ratio analysis. Tourism Management. 32(3), 604-615.

18. Cvijanović, D., \& Gajić, T., (2020). The Level of Engagement of the Female Workforce in the Rural Tourism Development of Serbia. Journal of Tourism Leisure and Hospitality, A Hospitality, Tourism, Travel and Leisure Sciences Journal, TOLEHO. Anadolu University, Faculty of Tourism. 2(1), pp.3642.

19. Eslami, S., Khalifah, Z., Mardani, A., Streimikiene, D., \& Han, H. (2019). Community attachment, tourism impacts, quality of life and residents' support for sustainable tourism development. Journal of Travel \& Tourism Marketing. 36(9), pp. 1061-1079.

20. Ertuna, B., \& Kırbaş, G. (2012). Local community involvement in rural tourism development: The case of Kastamonu, Turkey. Revista de Turismo y Patrimonio Cultura. 10 (2). Special Issue. pp. 17-24.

21. Fachrudin, H. T., \& Lubis, M. D. (2016). Planning for riverside area as water tourism destination to improve quality of life local residents, case study: BatuanSikambing River, Medan, Indonesia. Procedia-Social and Behavioral Sciences. 234(31), pp. 434-441.

22. Gajić, T., Radovanović, M., Tretiakova, T. and Syromiatnikova, J. (2020a). Creating brand confidence to gastronomic consumers through social networks - a report from Novi Sad. Journal of Place Management and Development. 14, 1. pp. 32-42.

23. Gajić, T., Petrović, M.D., Radovanovic, M., Tretiakova, T.N., Syromiatnikov, J.A. (2020b). Possibilities of Turning Passive Rural Areas into Tourist Attractions Through Attained Service Quality. European Countryside Journal. 12, 2, pp. 179-276.

24. Garau, C. (2015). Perspectives on cultural and sustainable rural tourism in a smart region: The case study of Marmilla in Sardinia (Italy). Sustainability .7, pp. 64126434.

25. Gursoy, D., Ouyang, Z., Nunkoo, R., \& Wei, W. (2018). Residents' impact perceptions of and attitudes towards tourism development: a meta-analysis. Journal of
Hospitality Marketing \& Management. 28(3), pp. 306-333.

26. Hai, A., \& Alamgir, B. (2017). Local community attitude and support towards tourism development at Saint Martin island, Bangladesh: Local community attitude and upport. International Journal of Tourism nd Hospitality Management in the Digital Age. 1(2), pp. 32-41.

27. Lee, T.H. (2013). Influence analysis of community resident support for sustainable tourism development. Tourism Management. 34, pp.37-46.

28. Lepp, A. (2007). Residents' attitudes towards tourism in Bigodi village, Uganda Case study. Tourism Management. 28, pp. 876-885.

29. Liang, Z. X., \& Hui, T. K. (2016). Residents' quality of life and attitudes toward tourism development in China. Tourism Management. 57, pp. 56-67.

30. Liu, J. C., Sheldon, P. J., \& Var, T. (1987). Resident perceptions of the environmental impacts of tourism. Annals of Tourism Research. 14, pp.17-37.

31. Li, Z. (2020). Development strategy of rural leisure tourism in the context of rural revitalization strategy on the public welfare of natural landscape resources. 04 , pp. 14-21.

32. Marin, D., Petroman, C., Petroman, I., Ciolac, R., \& Balan, I. (2009). Study regarding rural guest-house and agritourist household's number and percent in the total number of tourists' establishments in Romania. Lucr. Stiintifice Ser. Agron. 52, pp. 469-470.

33. Marzuki, A. (2011). Resident Attitudes towards Impacts from Tourism Development in Langkawi Islands, Malaysia. World Applied Sciences Journal. 12. Special Issue of Tourism \& Hospitality. pp. 25-34.

34. Mbaiwa, J. (2005). The Socio-cultural Impacts of Tourism Development in the Okavango Delta, Botswana. Journal of Tourism and Cultural Change. 2,3, pp.163185.

35. Meng F. (2014). Economic development, tourism. In: Jafari J., Xiao H. (eds) Encyclopedia of Tourism. Springer, Cham.

36. Moric, I. (2013). The Role and Challenges of Rural Tourism Development in Transition Countries: Montenegro Experiences. TURIZAM. 17(2), pp.84-95. 
37. Muresan, I., Oroian, C., Harun, R., Arion, F., Porutiu, A., Chiciudean, G., \& Lile, R. (2016). Local residents' attitude toward sustainable rural tourism development. Sustainability. $8(1), \quad 100$. doi.org/10.3390/su8010100.

38. Nagy, H., Káposzta, J., \& Meta, B. (2017). The potentials of rural tourism in developing rural areas in Albania. Deturope. 9(3), pp..188-206.

39. Naidoo, P., \& Sharpley, R. (2015). Local perceptions of the relative contributions of enclave tourism and agritourism to community wellbeing: The case of Mauritius. Journal of Destination Marketing \& Management. 5, pp. 16-25.

40. Negrusa, A.L., Cosma, S.A., \& Bota, M. (2007). Romanian rural tourism development: A study case in Maramures. International Journal of Business Research., 7, pp.129-135.

41. Nunkoo, R., \& Gursoy, D. (2012). Residents' support for tourism: An identity perspective. Annals of Tourism Research. 39(1), pp. 243-268.

42. Okech, R., Haghiri, M., \& George, P.B. (2012). Rurala tourism as a sustainable development alternative: an analysis with special reference to Luanda, Kenya. Sustainability, Tourism \& Environment in The Shift of A Millennium: A Peripheral View, 3, pp. 36-54.

43. Rasoolimanesh, S. M., Ringle, C. M., Jaafar, M., \& Ramayah, T. (2017). Urban vs. rural destinations: Residents' perceptions, community participation and support for tourism development. Tourism Management. 60, pp. 147-158.

44. Shariff, N.M.\& Abidin, A.Z. (2013). Community attitude towards tourism impacts: Developing a standard instrument in the Malaysian context. E-J. Soc. Sci. Res. 1, pp. 386-396.

45. Sinclair, M. G. (2017). Demographic Analysis of Residents' Support for Tourism Development in Jamaica. Journal of Destination Marketing \& Management. 6(1), pp.5-12.

46. Stylidis, D., Biran, A., Sit, J., \& Szivas, E.M. (2014). Residents' support for tourism development: The role of residents' place image and perceived tourism impacts. Tourism Management. 45, pp. 260-274.
47. Tao, H., Huang, Z., \& Ran, F. (2018). Rural Tourism Spatial Reconstruction Model from the Perspective of ATV: A Case Study of Mufu Township, Hubei Province, China. Sustainability. 10, pp. 2-17.

48. Tao, H., Liu, J. M., Deng, Y., \& Du, A. (2017). Tourism sectorization opportunity spectrum model and space partition of tourism urbanization area: A case of the Mayangxi ecotourism area, Fujian province. China. J. Mt. Sci. 14, ppp.595-608

49. Vuković, P., Arsić, S., \& Cvijanović, D. (2010). Konkurentnost ruralnih turističkih destinacija. Ekonomika poljoprivrede. 57(1), pp. 47-60.

50. Vukovic, P., Kljajic, N., \& Arsic, S. (2012). Multifunctional Agriculture as an Assumption and a Condition for Rural Development in Serbia: Special Turn to Rural Tourism. International Journal of Sustainable Economies Management (IJSEM). 1(2), pp. 24-32.

51. Wang, Y., \& Pfister, R.E. (2008). Residents attitudes toward tourism and perceived personal benefits in a rural community. Journal of Travel Research. 47, pp. 84-93.

52. Wang, S. (2013). Predicting Effects of Demographics and Moderating Power of Engagement on Residents' Perceptions of Tourism Development. European Journal of Tourism Research. 6(2), pp.170-182.

53. Xu, S., Barbieri, C., Anderson, D., Leung, Y.F., \& Rozier-Rich, S. (2016). Residents' perceptions of wine tourism development. Tourism Management, 55, pp.276-286.

54. Zeng S., Liu W., \& He J. (2019). Rural Revitalization: How to Develop Rural Tourism Guo Yanron. The renewal of rural tourism model based on Internet, Jushe. 34, p. 8.

55. Zhu, H., Liu, J., Wei, Z., Li, W., \& Wang, L. (2017). Residents' attitudes towards sustainable tourism development in a historical-cultural village: Influence of perceived impacts, sense of place and tourism development potential. $\begin{array}{lll}\text { Sustainability. } & 9(1),\end{array}$ doi.org/10.3390/su9010061.

56. Zhou Z. (2020). Research on the development path of characteristic small town under the perspective of rural revitalization. China Business Review. 14, pp. 161-163. 